\title{
ISOLATION, IDENTIFICATION AND BIOCHEMICAL CHARACTERIZATION OF VIBRIOS SPECIES FROM SHRIMP HATCHERIES NEAR PONDICHERRY COAST, TAMILNADU, INDIA
}

\author{
Dr. Vishnu Kiran Manam \\ Microbiology Division \\ Dr Yellapragada Lifesciences \\ Chennai, Tamilnadu, India
}

\author{
Dr. G. Sumathi \\ Department of Microbiology \\ Sri Muthukumaran Institute of Medical Sciences \\ Chennai, Tamilnadu, India.
}

\begin{abstract}
One of the major fastest growing food sectors globally seems to be the aquaculture industry which ensures a high protein resource to the world due to the exploitation of natural protein resources. One of the major problem in shrimp culture is the disease caused by the bacterial invasions particularly that of vibrios. Some of the important vibrio species that causes the devastation are Vibrio harveyi, Vibrio splendidus, Vibrio parahaemolyticus, Vibrio alginolyticus, Vibrio vulnificus, Vibrio damsella, Vibrio anguillarum, Vibrio orientalis etc. In the present study the vibrios associated with shrimp hatcheries near Pondicherry coast were isolated, identified and biochemical studies were performed along with the vibrio load from the water samples taken from the larval rearing section, post larval rearing section and nauplli. The isolated and identified vibrios were found out to be Vibrio vulnificus, Vibrio alginolyticus and Vibrio parahaemolyticus based on the biochemical characterization and by selective media plating.
\end{abstract}

Keywords - Aquaculture, Vibrios, Biochemical, Isolation, Identification.

\section{INTRODUCTION}

Vibrios have emerged as a major problem affecting shrimp culture across the world. The Outbreaks and mass mortalities of vibrios in hatcheries and grow out ponds of shrimp have been reported across many regions (Couch 1978; Overstreet 1978; Lightner 1983, 1985, 1988, 1996; Sindermann 1990; Ruangpan and Kitao 1991, 1992; Chen et al. 1992; Yang et al. 1992; de la Pena et al. 1993; Jiravanichpaisal et al. 1994; Mohney et al. 1994; Lavilla-Pitogo and de la Pena 1998; Lavilla-Pitogo et al. 1998). Vibriosis is caused by gramnegative bacteria belonging to the family Vibrionaceae. The outbreaks of vibrios may be due to the environmental factors which enhance the rapid multiplication of the bacteria which is present and tolerated in shrimp blood (Sizemore \& Davis, 1985) and also the other factor is the bacteria penetration of the host barriers. Some Vibrio species which are associated with multiple etiological agents become opportunistic pathogens when the natural defense mechanism are suppressed (Brock and Lightner, 1990) and are recognized as primary pathogens (Owens and Hall-Mendelin, 1989; Owens et al, 1992; Lavilla-Pitogo et al., 1990; de la Peña a et al., 1995) among them the pathogenic strains of $V$. harveyi, $V$. vulnificus and $V$. parahaemolyticus have been the major causative agents for the major epidemics in Thailand (Nash et al., 1992) and in Philippines (Lavilla-Pitogo et al., 1990). Vibriosis is among the most common rampant in the Indian subcontinent where shrimp hatcheries and farming are the core part of aquaculture activity. The invasion of luminous vibrios (Karunasagar et al. 1994; Hameed et al. 1996; Shome et al. 1999) has led to the shutdown of many units in the past and the problem seems to be severe in hatcheries. This article gives an account of the Vibrio spp. isolated and identified from the water samples of larval rearing, post larval rearing and nauplii samples and their treatment as well as the remedies to be taken in the elimination of vibrios from shrimp hatcheries.

\section{MATERIALS \& METHODS}

The water samples were collected randomly from the tanks of larval rearing, post larval rearing and from nauplii sections from three shrimp hatcheries located in the Pondicherry coast, Tamilnadu, India during January 2017 to December 2017. The water samples from the diseased shrimp from larval, post larval and nauplii sections were brought to the laboratory in a sterile container and were subjected to detailed bacteriological analysis which includes the estimation of vibrio loads, isolation, identification and biochemical characterization. 


\section{International Journal of Engineering Applied Sciences and Technology, 2019 \\ Vol. 4, Issue 7, ISSN No. 2455-2143, Pages 125-129 \\ Published Online November 2019 in IJEAST (http://www.ijeast.com)}

\section{ISOLATION AND IDENTIFICATION OF VIBRIOS}

The water samples $(0.5 \mathrm{~mL})$ each was inoculated on Thiosulphate Citrate Bile Sucrose Agar (TCBS) and Chromogenic Vibrio Agar. Total bacterial and Vibrio loads were estimated following standard methods (APHA 1992). The predominant and morphologically different colonies were selected and streaked on nutrient agar to obtain pure cultures. The isolated bacteria were identified based on morphological, physiological, and biochemical characteristics as given in HiVibrio Identification kit (KB007) and Bergey's Manual of Systematic Bacteriology (Baumann and Schubert 1984). The estimation of Vibrio load was calculated based on their colony forming units (CFU).

\section{RESULTS}

The Samples from larval rearing, post larval rearing and nauplii water were streaked and spread plate technique were performed on TCBS and Chromogenic vibrio agar. The colony morphology on TCBS agar showed three different colonies namely yellow translucent colonies, Mucoid yellow colonies and Mucoid green colonies, Similarly the colony morphology plated on Chromogenic vibrio agar showed three different colonies namely green blue/turquoise blue colonies, colorless colonies and Mauve/pink colonies. The biochemical reactions were performed using HiVibrio identification kit (KB007) and the following tests were performed such as voges proskauer's, arginine, salt tolerance (1\%), ONPG, citrate, ornithine, Mannitol, arabinose, Sucrose, Glucose, salicin and cellobiose. The Vibrios isolated and identified by the colony morphology from TCBS (Figure 1 \& Table 1), chromongenic vibrio agar (Figure $2 \&$ Table 1) and biochemical reactions (Table 1) are Vibrio vulnificus, Vibrio alginolyticus and Vibrio parahaemolyticus.

The vibrio loads and average colonies were monitored from January 2018 to December 2018 from the three hatcheries and their average CFU were determined from larval rearing section, post larval rearing section and nauplii water. In hatchery 1 (Figure 3 ) the larval rearing vibrio loads per year on an average were studied and $25 \mathrm{CFU}$ of $V$. vulnificus, $55 \mathrm{CFU}$ of $V$. alginolyticus and $5 \mathrm{CFU}$ of $V$. parahaemolyticus were estimated. Similarly the post larval rearing vibrio loads per year on an average were studied and $35 \mathrm{CFU}$ of $V$. vulnificus, $65 \mathrm{CFU}$ of $V$. alginolyticus and 10 CFU of $V$. parahaemolyticus were estimated. Again the nauplii water vibrio loads were also studied on an average per year and their CFU were determined which showed $45 \mathrm{CFU}$ of $V$. vulnificus, $95 \mathrm{CFU}$ of $V$. alginolyticus and $48 \mathrm{CFU}$ of $V$. parahaemolyticus.

In hatchery 2 (Figure 4) the larval rearing vibrio loads on an average per year showed $20 \mathrm{CFU}$ of $V$. vulnificus, $60 \mathrm{CFU}$ of $V$. alginolyticus and $7 \mathrm{CFU}$ of $V$. parahaemolyticus. Similarly $40 \mathrm{CFU}$ of $V$. vulnificus, $70 \mathrm{CFU}$ of $V$. alginolyticus, and $15 \mathrm{CFU}$ of $V$. parahaemolyticus were observed on an average per year. Finally the nauplii water vibrio loads were also determined which showed $55 \mathrm{CFU}$ of $V$. vulnificus, $95 \mathrm{CFU}$ of $V$. alginolyticus and $45 \mathrm{CFU}$ of $V$. parahaemolyticus.

In hatchery 3 (Figure 5) similar studies of vibrio loads were performed on an average per year, in the larval rearing section $20 \mathrm{CFU}$ of $V$. vulnificus, $60 \mathrm{CFU}$ of $V$. alginolyticus and $7 \mathrm{CFU}$ of $V$. parahaemolyticus. In the post larval section $40 \mathrm{CFU}$ of $V$. vulnificus, $70 \mathrm{CFU}$ of $V$. alginolyticus and $15 \mathrm{CFU}$ of $V$. parahaemolyticus were observed on an average per year. Finally the nauplii water vibrio loads on an average per year were determined which showed $55 \mathrm{CFU}$ of $V$. vulnificus, $95 \mathrm{CFU}$ of $V$. alginolyticus and $45 \mathrm{CFU}$ of $V$. parahaemolyticus.

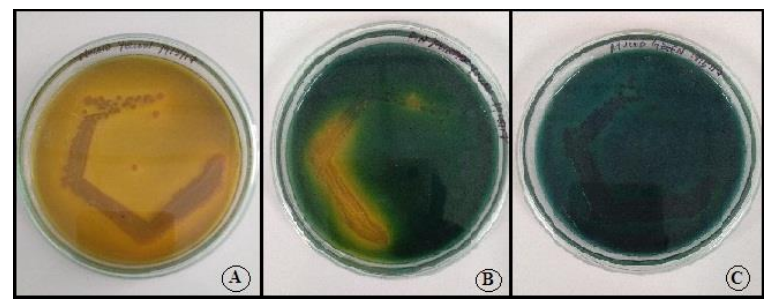

Fig. 1. Colony morphology on Thiosulfate-citrate-bile salts-sucrose (TCBS) agar

(a) Mucoid Yellow Colonies (b) Yellow Translucent Colonies (c) Mucoid Green Colonies

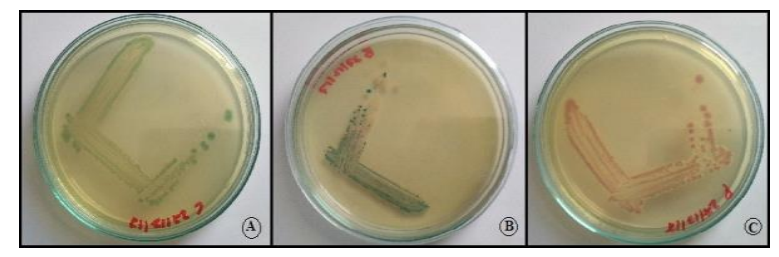

Fig. 2. Colony morphology on Chromogenic Vibrio (CV) agar (a) Colorless Colonies (b) Green Blue/Turquoise Blue Colonies (c) Mauve/Pink Colonies

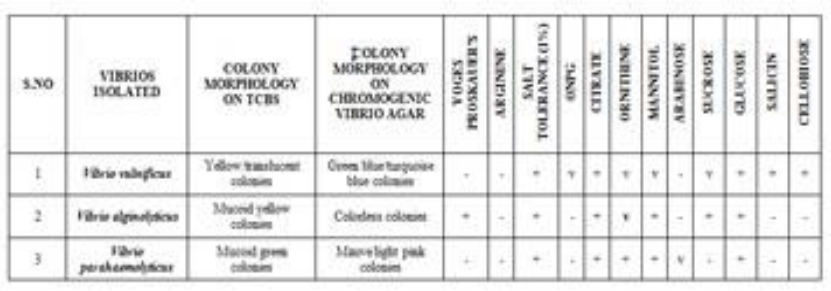

Table. 1. Colony morphology on Thiosulfate-citrate-bile saltssucrose (TCBS) agar, Chromogenic Vibrio (CV) agar and Biochemical reactions of the isolated vibrios. 


\section{International Journal of Engineering Applied Sciences and Technology, 2019 \\ Vol. 4, Issue 7, ISSN No. 2455-2143, Pages 125-129 \\ Published Online November 2019 in IJEAST (http://www.ijeast.com)}

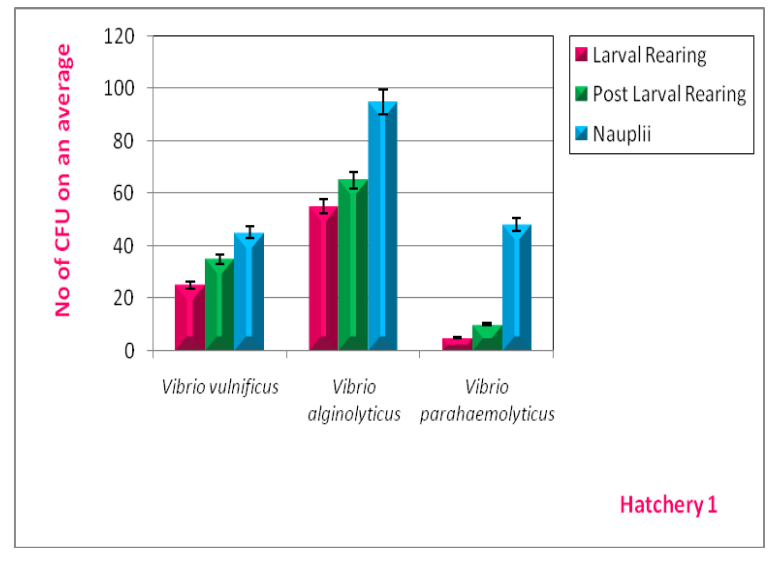

Fig. 3. No of CFU on an average/year from hatchery 1

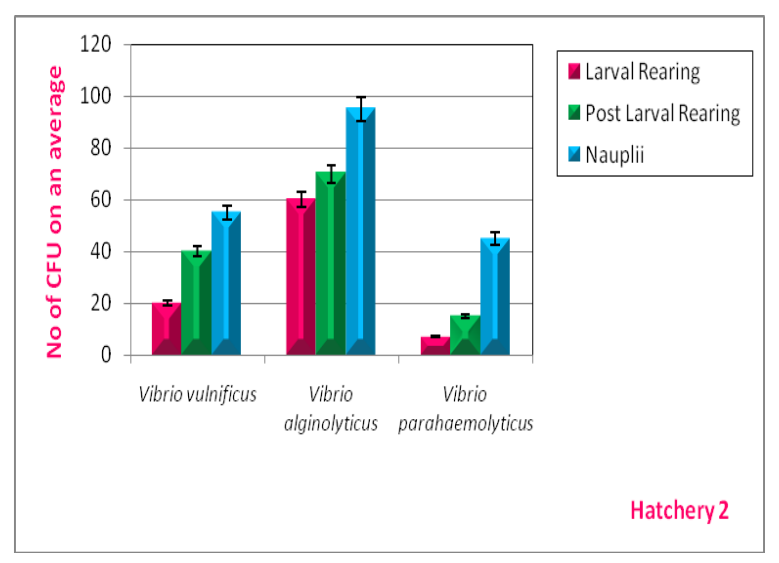

Fig. 4. No of CFU on an average/year from hatchery 2



Fig. 5. No of CFU on an average/year from hatchery 3

\section{DISCUSSION}

Vibrio vulnificus is a gram negative, motile, rod shaped bacillus belonging to the pathogenic category of the genus vibrios mostly present in marine environments like brackish ponds, coastal areas and estuaries (do Nascimento et al. 2001).
The seafood contaminated with V. vulnificus causes wound infections, septicemia and gastroenteritis. Reports indicate that 140 samples out of 239 showed positive for $V$. Vulnificus when quantifying their prevalence in shrimps were performed in china (Hua Ji et al., 2011). Vibrio alginolyticus is a halophilic, gram negative marine bacterium which causes ear, eye and wound infections in humans. Shrimp affected with Vibrio alginolyticus infections displayed poor growth, anorexia, inactivity, whitish musculature and reddish uropods as well as telson (Liu C.H et al. 2004). Vibrio parahaemolyticus a gram negative halophilic marine environment organism causes acute gastroenteritis and septicemia associated with wound infections in humans (Vengadesh et al. 2017). Vibrio parahaemolyticus is the causative agent of acute hepatopancreatic necrosis disease (AHPND) in the whiteleg shrimp from commercial farms (Patricia et al. 2016).

The present study confirms the presence of three vibriosis namely Vibrio vulnificus, Vibrio alginolyticus and Vibrio parahaemolyticus based on the selective biochemical characterization and media plating (TCBS \& Chromogenic Vibrio agar) isolated and identified from the larval rearing section, post larval section and nauplii water from three different hatcheries. The Vibrio loads from these three sections from the hatcheries were also studied and their colony forming units were analyzed during January 2017 to December 2017. The prophylactic action include good sanitation measures in hatcheries, proper biosecurity as well as rigorous water management can control the vibrios invasion in hatcheries (Baticados, et al, 1990). Another control measure includes an increase in daily water exchange will possibly reduce the vibrios to even a zero down point. Applications of probiotics which will reduce the vibrios effect as the prior will occupy and multiply in the medium leaving no space for the pathogenic vibrios to survive. The probiotic bacterial strains like Lactobacillus rhamnosus, Lactobacillus plantarum, Bacillus subtilis, Bacillus megaterium, Bacillus pumilus, Bacillus licheniformis, Pediococcus species, Carnobacterium showed promising activity against vibriosis (Laurent et al. 2000). Immunostimulants have also had their successful effect associated with Vibrios (Itami, 1996). Inactivated whole cell vaccine and peptidoglucan from bacterial derivatives seems to be better immunostimulants against vibriosis (Barman et al, 2013). The proper water management system in shrimp hatcheries such as using slow sand filtration, Rapid sand filtration, ozone and de-ozone treated water, UV filtration, cartridge filtration will help in minimizing the occurrence of vibriosis. The limited use of chemicals such as formalin and copper sulphate has a positive effect on vibrios elimination (Nakayama T et al. 2007). Vibriosis may be controlled in the hatchery by washing eggs with iodine and formaldehyde and avoiding contamination by spawner faeces. The study thus summarizes the isolation, identification, biochemical characterization and selective media plating of Vibrio vulnificus, Vibrio alginolyticus, Vibrio parahaemolyticus as 


\section{International Journal of Engineering Applied Sciences and Technology, 2019 \\ Vol. 4, Issue 7, ISSN No. 2455-2143, Pages 125-129 \\ Published Online November 2019 in IJEAST (http://www.ijeast.com)}

well as their loads on an average per year collected from larval rearing, post larval rearing and nauplii water from three different hatcheries near Pondicherry coast, Tamilnadu, India. This study also emphasizes on the prophylactic or control measures of the vibrios in hatcheries which was extensively discussed.

\section{CONCLUSION}

The Vibrios which are found to be the causative agent for reduced productivity in shrimp hatchery health management can be effectively controlled by the use of appropriate water and gut probiotics as well as indigenous preparation of probiotics as most of the vibrios are site specific. The use of immunostimulants in hatchery aquaculture might boost the immune system of the larval health of the animal in combating the pathogenic vibrios and increase in the productivity of the larval and post larval sections of the shrimp hatchery. Thus the probiotics and immunostimulants act as the prophylactic measure as "Prevention is better than cure"

\section{ACKNOWLEDGEMENT}

The authors would like to acknowledge the shrimp hatcheries near Pondicherry for their support in collection of samples as well the technicians who extended their support in the completion of the research.

\section{REFERENCE}

[1]. Couch, J. A. (1978). Diseases, Parasites and toxic responses of commercial penaeid shrimps of the Gulf of Mexico and South Atlantic coasts of North American. Fishery Bulletin, Vol. 76, (Pg. 1-44).

[2]. Overstreet, R. M. Marine maladies. (1978). Worms, germs and other symbionts from the Northern Gulf of Mexico. Mississippi Alabama Sea Grant Consortium, Ocean Springs, Mississippi, USA.

[3]. Lightner, D. V. (1983). Diseases of cultured penaeid prawn in J.P. McVeigh, editor. CRC Hand Book of Mariculture, Vol. 1. Crustacean Aquaculture. CRC Press, Boca, Raton, Florida, USA, (Pg. 289-320).

[4]. Lightner, D. V. (1985). A review of the diseases of cultured penaeid shrimps and prawns with emphasis on recent discoveries and developments in Proceedings of the first International Conference. Culture of penaeid prawns and shrimps. Illio, Philippines, (Pg. 79-103).

[5]. Lightner, D. V. (1988). Vibrio disease of penaeid shrimp in C.J. Sindermann and D. V. Lightner, editors. Disease diagnosis and control in North American Marine Aquaculture, 2nd edition. Elsevier, New York, New York, USA, (Pg. 4247).

[6]. Lightner, D. V. (1196). Handbook of shrimp pathology and diseases of cultured penaeid shrimp. World Aquaculture Society, Baton Rouge, Louisiana, USA.
[7]. Sindermann, C. J. (1990). Principal diseases of marine fish and shell fish, volume 2. Diseases of marine shell fish, 2nd edition. Academic Press, Inc.

[8]. Ruangpan, L., and Kitao J. (1991). Vibrio bacteria isolated from diseased tiger prawn, P. monodon. Journal of Fish Diseases, Vol. 14, (Pg. 283-288).

[9]. Ruangpan, L., and Kitao J. (1992). Minimal inhibitory concentrations of 19 chemotherapeutants against Vibrio bacteria of shrimp Penaeus monodon. Pages 135-142 in M. Shariff et al., editors. Diseases of Asian aquaculture. I. Fish Health Section. Asian Fisheries Society, Manila, Philippines, (Pg. 135-142).

[10]. Chen, S. N., S. L. Huang, and G. H. Kou. (1992). Studies on the epizootiology and pathogenicity of bacterial infections in cultured giant tiger prawns, Penaeus monodon, in Taiwan. Pages 195-205 in W. Fulkas and K. L. Main, editors. Diseases of cultured penaeid shrimp in Asia and the United States. Hawaii Oceanic Institute.

[11]. Yang, J., X. Wu, and S. Zu. (1992). Observations on black spot on shell disease of cultivated penaeid shrimp by SEM. Donghai Marine Science, Vol. 11, (Pg. 34-39).

[12]. De la Pena, L. D., T. Tamaki, K. Momoyama, Nakai, and K. Muroga. (1993). Characteristics of the causative bacterium for vibriosis in the kuruma prawn, Penaeus japonocus. Aquaculture, Vol. 115, (Pg. 1-12).

[13]. Jiravanichpaisal, P., T. Miyazaki, and C. Limsuwan. (1994). Histopathology, biochemistry and pathogenicity of Vibrio harveyi infecting black tiger prawn, Penaeus monodon. Journal of Aquatic Animal Health, Vol. 6, (Pg. 27-35).

[14]. Mohney, L., T. A. Bell, and D. V. Lightner. (1994). An epizootic of vibriosis in Equadorian pond-reared Penaeus vannamei Boone (Crustacea: Decapoda). Journal of World Aquaculture Society, Vol. 25, (Pg. 116-125).

[15]. Lavilla-Pitogo, C. R. and L. D. de la Pena. (1998). Bacterial diseases in shrimp (Penaeus monodon) culture in Philippines. Fish Pathology, Vol. 33, (Pg. 405-411).

[16]. Lavilla-Pitago, C. R., E. M. Leano, and M. G. Paner. (1998). Mortalities of pond-cultured juvenile shrimp, Penaeus monodon, associated with dominance of luminescent Vibrios, in the rearing environment. Aquaculture, Vol. 164, (Pg. 337349).

[17]. Sizemore R. K, Davis J. W. (1985). Source of Vibrio spp. found in the hemolymph of the blue crab Callinectes sapidus. J Invertebr Pathol, Vol. 46, (Pg. 109-110).

[18]. Brock, J.A. and Lightner, D.V. (1990). Diseases of Crustacea. In: O. Kinne (ed.) Diseases of Marine Animals Vol. 3, Biologische Anstalt Helgoland, Hamburg, (Pg. 245-424).

[19]. Owens, L. and Hall-Mendelin. (1989). Recent Advances in Australian shrimps (sic) diseases and pathology. Advances in Tropical Aquaculture, Tahiti, AQUACOP, IFREMER, Actes de Colloque, Vol. 9, (Pg. 103-112).

[20]. Owens, L., Muir, P., Sutton, D. and Wingfield, M. (1992). The pathology of microbial diseases in tropical Australian Crustacea. In: M. Shariff, R.P. Subasinghe and J.R. Authur (eds.) Diseases in Asian Aquaculture 1. Fish Health 


\section{International Journal of Engineering Applied Sciences and Technology, 2019 \\ Vol. 4, Issue 7, ISSN No. 2455-2143, Pages 125-129 \\ Published Online November 2019 in IJEAST (http://www.ijeast.com)}

Section, Asian Fisheries Society, Manila, Philippines, (Pg. 165-172).

[21]. Lavilla-Pitogo, C.R., Baticados, C.L., Cruz-Lacierda, E.R. and de la Pena, L. (1990). Occurrence of luminous bacteria disease of Penaeus monodon larvae in the Philippines. Aquaculture, Vol. 91, (Pg. 1-13).

[22]. de la Peña, L.D., Kakai, T, Muroga, K. (1995). Dynamics of Vibrio sp PJ in organs of orally infected kuruma shrimp, Penaeus japonicus. Fish. Pathol, Vol. 30, (Pg. 39-45). [23]. Nash, G. Nithimathachoke, C., Tungmandi, C., Arkarjamorn, A., Prathanpipat, P. and Ruamthaveesub, P. (1992). Vibriosis and its control in pond-reared Penaeus monodon in Thailand. In: M. Shariff, R.P. Subasinghe and J.R. Authur (eds.) Diseases in Asian Aquaculture 1. Fish Health Section, Asian Fisheries Society, Manila, Philippines, (Pg. 143-155).

[24]. Lavilla-Pitogo, C.R., Baticados, C.L., Cruz-Lacierda, E.R. and de la Pena, L. (1990). Occurrence of luminous bacteria disease of Penaeus monodon larvae in the Philippines. Aquaculture, Vol. 91, (Pg. 1-13).

[25]. Karunasagar, I., R. Pai, G. R. Malathi, and I. Karunasagar. (1994). Mass mortalities of Penaeus monodon larvae due to antibiotic resistant Vibrio harveyi infection. Aquaculture, Vol. 128, (Pg. 203-209).

[26]. Hameed, A. S. S., J. J. Farmer, F. W. HickmannBrenner, and G. R. Farming. (1996). Characteristics and pathogenicity of a Vibrio campbelli like bacterium affecting hatchery reared P. indicus (Milne Edwards 1837) larvae. Aquaculture Research, Vol. 27, (Pg. 853-863).

[27]. Shome, R., B. R. Shome, and R. Soundararajan. (1999). Studies on luminous Vibrio harveyi isolated from Penaeus monodon larvae reared in hatcheries in Andamans. Indian Journal of Fisheries, Vol. 46, (Pg. 141- 147).

[28]. Hua Ji, Yan Chen, Yunchang Guo, Xiumei Liu, Jian Wen, and Hong Liu. (2011). Occurrence and characteristics of vibrio vulnificus in retail marine shrimp in china. Food Control, Vol. 22, Issue. 12, (Pg. 1935-1940).

[29]. do Nascimento S.M, dos Fernandes Vieira R.H, Theophilo G.N, Dos Prazeres Rodrigues D, Vieira G.H. (2001). Vibrio vulnificus as a health hazard for shrimp consumers, Vol. 43, Issue 5, (Pg. 263-266).

[30]. Liu, C.H., Cheng W, Hsu J.P and Chen J.C. (2004). Vibrio alginolyticus infection in the white shrimp Litopenaeus vannamei confirmed by polymerase chain reaction and $16 \mathrm{~S}$ rDNA sequencing. Dis Aquat Organ, Vol. 61, Issue 1-2, (Pg. 169-174).

[31]. Vengadesh, L., Kok-Gan C and Learn-Han L. (2014). Vibrio parahaemolyticus: a review on the pathogenesis, prevalence, and advance molecular identification techniques. Front Microbiol, Vol. 5, (Pg. 705).

[32]. Patricia L.L., Antonio L.G, Ruth E.M, María del Carmen F.M, Jesús A. Fierro-Coronado Píndaro Álvarez-Ruiz and Genaro Diarte-Plata. (2016). Isolation and characterization of infectious Vibrio parahaemolyticus, the causative agent of
AHPND, from the whiteleg shrimp (Litopenaeus vannamei). Lat. Am. J. Aquat. Res, Vol. 44, Issue 3, (Pg. 470-479).

[33]. Barman, D., Nen P, Mandal S.C, and Kumar V. (2013). Immunostimulants for Aquaculture Health Management. J Marine Sci Res Dev, Vol. 3, (Pg. 134).

[34]. Laurent, V., Geert R, Patrick S and Willy V. (2000). Probiotic Bacteria as Biological Control Agents in Aquaculture. Microbiol Mol Biol Rev, Vol. 64, Issue 4, (Pg. 655-671).

[35]. Nakayama, T., N. Nomura, and M. Matsumura. (2007). The effect of copper concentration on the virulence of pathogenic Vibrio harveyi, Journal of Applied Microbiology, Vol. 102, Issue 5, (Pg. 1300-1306). 